\title{
Determining annual cryosphere storage contributions to streamflow using historical hydrometric records
}

Brahney, Janice ${ }^{\mathrm{a} *}$, Menounos, Brian ${ }^{\mathrm{b}}$, Wei, Adam ${ }^{\mathrm{a}}$, Curtis, Paul Jefferson ${ }^{\mathrm{a}}$

a Department of Earth and Environmental Sciences, University of British Columbia, Okanagan. Kelowna, BC V1V 1V7, Canada, janice.brahney@usu.edu, Jeff.Curtis@ubc.ca, Adam.Wei@ubc.ca

${ }^{\mathrm{b}}$ Geography Program and Natural Resources and Environmental Studies Institute, University of Northern British Columbia, Prince George, BC V6T 1Z9, Canada. Brian.Menounos@unbc.ca

*Corresponding Author, janice.brahney@usu.edu, 435-797-4479

Current Address: Department of Watershed Sciences, Utah State University, Logan UT, 84322, USA 


\begin{abstract}
Alpine glaciers and perennial snow fields are important hydrologic elements in many mountain environments providing runoff during the late summer and during periods of drought. Because relatively long records of glacier mass-balance data are absent from many glacierized catchments, it remains unclear to what extent shrinking perennial snow and glaciers have affected runoff trends from these watersheds. Here we employ a hydrograph separation technique that uses a double mass curve in an attempt to isolate changes in runoff due to glacier retreat and disappearance of perennial snow. The method is tested using hydrometric data from 20 glacierized and 16 non-glacierized catchments in the Columbia Basin of Canada. The resulting estimates on cryosphere storage contribution to streamflow were well correlated to other regional estimates based on measurements as well as empirical and mechanistic models. Annual cryosphere runoff changed from +19 to $-55 \%$ during the period 1975-2012, with an average decline of $26 \%$. For August runoff, these changes ranged from +17 to $-66 \%$, with an average decrease of $24 \%$. Reduction of cryosphere contributions to annual and late summer flows are expected to continue in coming decades as glaciers and the perennial snow patches shrink. Our method to isolate changes in late summer cryospheric storage contributions can be used as a first order estimate on changes in glacier contributions to flow and may help researchers and water managers target watersheds for further analysis.
\end{abstract}

Key words: Glacier melt, Double Mass Curve, Glacier runoff, British Columbia, Hydrograph Separation, Cryosphere

\title{
Abbreviations
}

CSC Cryosphere Storage Contribution

CB Columba Basin

DMC Double Mass Curve

HS-DMC Hydrograph Separation method informed by a Double Mass Curve. 


\subsection{Introduction}

Glaciers and perennial snow fields represent a critical source of freshwater that is stored within a catchment. This resource provides needed water to streams during the late summer season when annual snowmelt has abated and further delivers critical meltwater to streams during drought years. These attributes not only provide flow consistency, but maintain the cooler stream temperatures needed by coldwater fish for spawning and migration (Moore et al. 2009). Further, the heavy sediment loads from glaciers and the subsequent channel modifications maintain streambed habit and the conditions necessary for many endemic invertebrates (Hari et al. 2006, Young and Woody 2007, Muhlfeld et al. 2011). Therefore, the loss of glacier and perennial snow melt contributions to late summer flow can have negative consequences for stream ecosystems. Moreover, approximately one half of the world relies on freshwater runoff from mountains systems. Going forward, climate change will further stress this resource by increasing water demands in the late summer for energy, irrigation, and domestic use (Cohen et al. 2000, Payne et al. 2004). For these reasons, there is considerable interest in understanding how climate change may affect glacier contributions to streamflow around the world.

The response of glaciers to climate change can be both immediate and delayed (Beedle et al. 2009, Moore et al. 2009) and so present-day retreat reflects integrated changes over decades or more. Loss of glacier mass can have a short-term (primary) and long-term (secondary) effect on glacier melt contributions to streamflow. The short-term response is often an increase in meltwater production because the snow line rises and the areas of firn that could temporarily store meltwater during summer are reduced. If conditions favoring strong thinning and glacial retreat continue, however, this increase in meltwater production eventually declines as the total area of the glacier decreases (Fleming and Clarke 2003, Collins 2008, Moore et al. 2009, Clarke et al. 2015).

Glaciers are retreating at unprecedented rates in many regions of the world (Marzeion et al. 2014). Therefore, quantifying how glacier and perennial snow contributions to streamflow are changing through 
time is critical for effectivity preparing and managing for changes in the availability of this resource. However, long-term records of glacier contribution to streamflow do not exist for the many glaciated regions around the world. There have been several attempts to quantify how glacier retreat affects surface runoff using a variety of techniques including measurements (e.g. Gascoin et al. 2011, Huss 2011) empirical approaches (e.g. Fleming and Clarke 2003, Stahl and Moore 2006), physically-based models (e.g Comeau et al. 2009, Jost et al. 2012, Clarke et al. 2015) or a combination of these methods (e.g. Hopkinson and Young 1998, Stahl et al. 2008a, Hirose and Marshall 2013). Quantifying how glacier and perennial snow retreat affects streamflow is hampered in many regions by a number of factors that primarily include: (i) an insufficient number and temporal length of glacier mass-balance records from a region; and (ii) a lack of suitably long streamflow records to calibrate and validate hydrologic models. This deficit of information can limit both the understanding of historical climate-meltwater relationships in a given region and future projections of meltwater availability.

Here, we demonstrate the use of a statistical method to isolate the magnitude and change of late summer cryosphere flows that can be used in any region where suitable hydrologic records exist. We apply this method to watersheds with glacierized streams and compare our results to those acquired through alternative methods. Our method identifies changes in the late summer cryosphere contribution to streamflow, which likely includes flows from both glaciers and perennial snowfields. The resulting analyses yields time-series that provide first-order estimates of increases or decreases of cryosphere melt contributions to streamflow.

\subsection{Study Area and Methods}

\subsection{Study Region}

The Columbia River Basin drains $668,220 \mathrm{~km}^{2}$ of mountainous terrain that includes six US states and one Canadian province (Figure 1). The Canadian portion of the basin covers approximately 100,000 $\mathrm{km}^{2}$, representing about $15 \%$ of watershed. In this region, approximately $40 \%$ of the annual precipitation 
falls as snow from October to March (Canada n.d.). As of 2005, the Canadian portion of the Columbia Basin contains over $1,800 \mathrm{~km}^{2}$ of glacierized terrain (Bolch et al. 2010), and glacier melt is estimated to contribute 25-50\% of late summer streamflow (Brugman et al. 1996, Jost et al. 2012, Hirose and Marshall 2013). Runoff primarily from melting seasonal snow cover and glaciers (melt and wastage) produces more than $50 \%$ of the energy needs for the Pacific Northwest and British Columbia through hydroelectric generation (CBT 2016, NWPCC 2016).

Surface air temperatures in the Canadian Columbia Basin warmed by $1.4^{\circ} \mathrm{C}$ over the past century, and this warming primarily occurred during the 1930's and after 1980 (Murdock et al. 2007). Most glaciers in western Canada and the US have been retreating since the late 1800's with some glaciers advancing during the cool, wet period between 1950 and 1980 (Luckman et al. 1987, Dyurgerov and Meier 2005, Beedle et al. 2015) . Mass-balance data is available since the mid-1960's for three glaciers in British Columbia, though none is within the Canadian Columbia Basin. The monitored glaciers include the Place and Helm glaciers in the Pacific Coast ranges, and the Peyto Glacier in the Canadian Rockies. All three glaciers indicate consistent negative mass-balances since record keeping began, with a cumulative loss of 25-35 m water equivalent (w.e) from 1980 to 2012 (Demuth 2013, DeBeer et al. 2015, Medwedeff and Roe 2016). To put these glaciers in a global perspective, the World Glacier Monitoring Service reports that in the 2014-2015 balance year, the 37 global reference glaciers had an average cumulative thickness loss of more than $18.5 \mathrm{~m}$ w.e since 1980 (WGMS 2015). Between 1985 and 2005 percent glacier cover in the Columbia Basin decreased by 14\% (Bolch et al. 2010), with some individual glaciers losing up to $60 \%$ of their surface area (Murdock et al. 2007).

Previous work on modeling glacier contributions to streamflow in the region have found somewhat conflicting results. Stahl and Moore (2006) applied linear regression methods that use climate variables (temperature, precipitation) and July streamflow to account for inter-annual climate variability on August streamflow with the residual pattern reflecting changes in glacier contribution. Based on their results, they concluded that much of southern BC has entered the secondary phase where glacier 
contributions to streamflow are declining. However, this analysis was restricted to August cryosphere contributions to streamflow as a dimensionless value and therefore does not provide an estimate of annual changes in glacier contributions. Mechanistic modeling efforts in the region, however, have found no significant changes in glacier contributions to streamflow for large areas of the Columbia Basin (Jost et al. 2012).

\subsection{Hydrologic Data and Hydrograph separation}

We obtained runoff data for the Canadian portion of the Columbia Basin from the Water Survey of Canada (WSC). Our data include mean daily flows from glacierized $(n=20)$ and non-glacierized $(n=16)$ basins; percent glacier cover for the glacierized subset of our data ranges from < 1 to $19 \%$ (Table 1). We isolate late summer flows by pairing glacierized and non-glacierized daily streamflow using a Double Mass Curve (DMC) approach. The DMC method is commonly used to evaluate differences in watershed yield that occur through landscape changes (e.g. Yao et al. 2012, Liu et al. 2015). In the absence of a landscape effect, the DMC produces a strong linear relationship (Figure 2a,b); however, when hydrologic changes occur due to different landscape features, breaks in slope are easy to observe. Here, we use DMCs to compare hydrologic variability between glacierized and non-glacierized streams (Figure 2c,d).

Our method detects the amount of late summer runoff produced from glacierized catchments through time, which we interpret as net cryosphere storage contributions (CSC) to streamflow. We refrain from interpreting these changes as arising from ice wastage since these late summer flows could also originate from changes in the storage of perennial snow cover. For glaciers and perennial snow banks in climatic equilibrium we would expect to see no significant trend in the CSC to river flow using our DMC approach. A decreasing trend in CSC through time could indicate: 1) CSC contributions to streamflow are declining, or 2) comparatively less precipitation is occurring at high altitudes than low altitudes through the time periods in question. We evaluate whether or not winter precipitation has increased at low elevations in comparison to high elevation by analyzing trends in snow pillow data (FLNRO 2014). Time- 
series data were created from automated snow-pillow data by determining the maximum accumulated precipitation per hydrologic year.

To determine annual CSC, each glacierized stream is paired with four-to-six non-glacierized streams. Selection of comparative non-glacierized streams was determined by the capacity of the nonglacierized stream to capture the yield and dynamics of early annual snowmelt in the glacierized stream prior to the onset of glacier contributions. Suitable non-glacierized streams were determined by evaluating the correlation coefficient between paired streams for the first 180 days of the year, if the $r$ was greater than 0.85 the non-glacierized stream was used in the analysis. The strength of the regression equation between stream-pairs for the first 180 days of the year is also used in the error estimation described below. All stream-pairs have mean catchment elevations within $500 \mathrm{~m}$ of each other, with an average difference of $141 \pm 47 \mathrm{~m}$.

The DMC is derived by comparing the cumulative daily specific discharge (discharge/catchment area) between the glacierized stream in question and a representative non-glacierized stream. The onset and termination of late summer flows in any given year is initially determined by the slope of the DMC. The onset of late summer flow (DateOn) is defined as the date at which the slope increases over the average slope within the first 180 days of the year whereas its termination is the date when the slope falls below this threshold (Figure 3). Because the elevation of the non-glacierized catchments were for the most part lower than the glacierized ones, we scaled the daily specific discharges to the specific discharge sum prior to the onset of glacier flow (Figure 4):

$$
Q^{\prime}=\frac{Q}{\sum Q_{(1-\text { Dateon })}}
$$

Where Q' represents the scaled streamflow, Q is the streamflow, and DateOn is the date of glacier melt onset as determined by the DMC. The resulting hydrographs from each of the non-glacierized streams provide a proportional estimate of streamflow in the absence of perennial snow and ice contributions (Figure 4a). The volume of scaled CSC is determined by subtracting the non-glacierized 
scaled hydrograph from the scaled glacierized hydrograph (Figure 4b). Finally, we denormalize the estimates of the scaled CSC:

$$
C S C=\operatorname{CSC}^{\prime} *\left(\frac{\sum Q G_{(1-\text { Dateon })}+\sum Q N G_{(1-\text { Dateon })}}{2}\right)
$$

Where CSC' is the scaled CSC, QG represents the streamflow of the glacierized stream, QNG the streamflow in the non-glacierized stream, and CSC the cryosphere storage contribution in mm. Error in the empirical model is calculated by a pooled standard deviation from the standard error of the estimate as determined in the regression analyses and the standard deviation based on the estimates for all the streampairs. Because we compare each glacierized stream to multiple non-glacierized streams, we incorporate the regional variability in annual precipitation. Though this process was automated, each pair in each year was manually checked against temperature and precipitation data and corrected for potential errors. From herein we describe this method as the Hydrograph Separation by Double Mass Curve method (HS-DMC).

\subsection{Trends in Cryosphere Storage Contribution}

We evaluated trends in the mean estimated CSC to streamflow using the Spearman Rank correlation test for both the annual and August time-series. August was isolated because glacier contributions to flow typically comprise a relatively large fraction of this month's total runoff, and as such represents a critical source of water during this time of year (Moore et al. 2009). We estimated percent declines in CSC between 1975 and 2012, using the regression equations derived within this time period. This interval was chosen because the majority of glacierized streams have continuous data through this time-period. Finally, we isolate the effects of catchment characteristics on cumulative CSC by fitting a regression model using maximum elevation, latitude, and glacier area with each catchment:

$$
\mathrm{Q}_{\mathrm{csc}}=\mathrm{b}_{0}+\mathrm{b}_{1} \mathrm{E}_{\mathrm{MAX}}+\mathrm{b}_{2} \mathrm{~L}+\mathrm{b}_{3} \mathrm{G}_{\% \mathrm{AREA}}
$$

Where $\mathrm{Q}_{\mathrm{csc}}$ is the cumulative CSC between 1975-2012, $\mathrm{E}_{\mathrm{MAX}}$ is the maximum elevation in the glacierized catchment, and $\mathrm{G}_{\% \text { AREA }}$ is the percent coverage of glaciation within the catchment. 


\subsection{Model evaluation}

We evaluated our method to isolate late summer flows from glacierized catchments against other empirical and physically based approaches. To evaluate our results against mechanistic modeling efforts at a high temporal resolution (daily), we compared our results to those of Hirose and Marshall (2013) for the Illecillewaet basin for the melt years of 2009, 2010, and 2011. Hirose and Marshall (2013) measured mass-balance and meteorological data from the Illecillewaet glacier from 2009-2011 and used a distributed hydrologic model to quantify glacier melt from all 79 glaciers from May 1 to September 14. We compared our daily CSC to the glacier melt derived from Hirose and Marshall (2013) using regression analysis. Because the distributed model data represent melt at the glacier toe whereas the HS-DMC represents CSC at the gauging site $60 \mathrm{~km}$ downstream, we lagged the modeled streamflow by one day before calculating the Pearson correlation coefficients. The daily modeled melt data were graciously provided by Hirose and Marshal.

To evaluate our method against other empirical methods, we compared our data to that of Stahl and Moore (2006). Stahl and Moore (2006) used a regression model relating August streamflow to temperature, precipitation, and July discharge in order to back out glacier contributions to streamflow.

$\mathrm{Q}_{A u g(\mathrm{t})}=\mathrm{b}_{0}+\mathrm{b}_{1} \mathrm{Q}_{J u l(\mathrm{t})}+\mathrm{b}_{2} \mathrm{~T}_{A u g(\mathrm{t})}+\mathrm{b}_{3} \mathrm{P}_{A u g(\mathrm{t})}+\mathrm{e}(\mathrm{t})$

In their method, $\mathrm{Q}$ is the mean discharge, $\mathrm{T}$ is the mean air temperature, $\mathrm{P}$ is the total monthly precipitation, $b_{i}$ are the coefficients, and e is the residual (observed - predicted). They hypothesize that negative trends in the residual (e) would reflect the sustained negative mass-balances and retreat of glaciers in the watershed. We apply their method for each glacierized stream using precipitation and temperature data from nearby climate stations; climate data were obtained from the Pacific Climate Impacts Consortium Data Portal (PCIC n.d.). We compared our z-scored CSC results for the month of August to z-scored results from the Stahl and Moore (2006) method using a regression analysis. This 
allowed for a spatial comparison of the regional variability in CSC slope and the inter-annual variability derived from each method.

Finally, we calculated estimated volume losses by multiplying our CSC estimates in mm by the glacier area within each glacierized catchment. We compared our volumetric estimates to glacier volume wastage determined by Schiefer et al. (2007). This comparison allows us evaluate our estimates of volumetric losses against a physically-based method across spatial scales during a given period of time. The strength of the agreement between the HS-DMC method and those from Schiefer et al. (2007) was determined through regression.

Because glacierized catchments tend to be higher in elevation than non-glacierized catchments and thus receive more precipitation, our method has the potential to overestimate CSC to streamflow. To determine the potential magnitude of the bias, we use the maximum snow water equivalents from nine snow pillow stations in the Columbia Basin (Figure 1) to determine a snow water equivalent lapse rate with elevation. We then used this lapse rate to determine the potential inflation factor for any given stream-pair, and use the mean of all stream-pairs as our overall inflation factor for each glacierized catchment.

\subsection{Results}

\subsection{Trends in snowfall through time}

Snow pillow site elevations ranged from 1595 to $2090 \mathrm{~m}$ above sea level (asl). We found no significant trends in the snowfall accumulation data through time at any elevation. A caveat is that existing snow stations are all at or below treeline, and a significant proportion of the basin exists above this datum. As such, trends above treeline are difficult to determine. However, modeling evidence suggests that the higher elevation snowpack is increasing with respect to lower elevations (Schnorbus et al. 2011). 


\subsection{Catchment characteristics and Cryosphere Storage Contribution (CSC)}

The individual CSC to streamflow are correlated to the percent glacier cover for each catchment with an $r^{2}$ of $0.86(p<0.001)$. A weaker yet significant relationship also existed between the glacierized

area within each catchment $\left(\mathrm{km}^{2}\right)$, and the mean percent contribution to streamflow $r^{2}$ of $0.35, p<0.01$. Regressing latitude, maximum elevation, and percent glacier cover against cumulative CSC for a common period (1975-2012) explained $92 \%$ of the variance $(p<0.001)$. Independently, cumulative CSC was correlated to latitude by an $r^{2}$ of $0.57, p<0.001$, to max elevation with an $r^{2} 0.23, p=0.31$, and as above to percent glacier area in the catchment.

\subsection{Trends in Cryosphere Storage Contribution}

Nineteen of twenty glacierized streams showed declines in CSC through their period of record. Based on Spearman Rank correlation analyses, eight were significant at $p<0.1$ (Table 1); sixteen showed significant declines of CSC for August streamflow at $p<0.1$ (Table 1). Annual declines through the full period of record ranged from 0 for Canoe Creek to $-61 \%$ for the Lardeau River. August CSC declines ranged from $1 \%$ for Beaver Creek to $62 \%$ for Blue River. The largest percent declines were calculated for the streams within median latitudes and with median percent glacier cover (Table 1, Figure 5). Given the potential influence of varied start/end periods in trend detection, we also evaluate the percent CSC changes through the 1975-2012 period, a time period common to most streams of our study (Figure 5). Time series graphs for all catchment CSC to streamflow are available in the Supplementary Figures.

We estimated the potential inflation in the CSC to streamflow based on the determined snow water equivalent lapse rate. The inflation factors are presented in Table 1 for each glacierized catchment. The lapse rate was approximately of $65 \mathrm{~mm}$ per $100 \mathrm{~m}$, though the regression was not well-constrained and the error is approximately $+/-71 \mathrm{~mm}$ per $100 \mathrm{~m}$. 


\subsection{Model evaluation}

The HS-DMC method compares favorably (Figure 6) to the magnitude and diurnal variability of glacier runoff presented by Hirose and Marshall (2013). The HS-DMC was correlated to the modeled data with significant $(p<0.001)$ Pearson correlation values of $0.84,0.90$ and 0.83 respectively for hydrologic years 2009, 2010, and 2011. The annual contributions of late summer cryospheric runoff to streamflow for the years 2009, 2010 and 2011 using the HS-DMS method are 18, 10.1 and $8.3 \%$ whereas the distributed model yielded 14.4, 10.6, and 5.8\%.

Our HS-DMC method applied to August flows show moderate-to-strong correlation $(0.33<\mathrm{r}<$ 0.95 , average $=0.67)$ to the inter-annual late-summer flows produced by the Stahl and Moore (2006) method (Figure 7). We found no significant differences between the magnitude of the z-scored trends between the two methods.

We compared our results to the those from Schiefer et al. (2007) by regressing the glacier wastage volume estimates $\left(\mathrm{m}^{3}\right)$ against the product of our CSC $(\mathrm{mm})$ and glacier area $\left(\mathrm{km}^{2}\right)$ multiplied by 1000 to scale the data to $\mathrm{m}^{3}$. The two datasets were correlated with an $r^{2}$ of 0.71 , however our estimated volumes are on average 3.7x greater than the estimates by Schiefer et al. (2015). The reason for the discrepancy are potentially due to 1) errors in the TRIM data used to estimate changes in glacier area in the Schiefer et al. (2015) estimates, and 2) a combination of melt from the perennial snow pack and inflation due to strong precipitation lapse rates.

\subsection{Discussion}

Our method represents a simple yet effective approach to assess changes in the timing and magnitude of late summer flows from basins that contain perennial snow and glaciers. The HS-DMC approach accords with other empirical techniques based on physical hydrologic models. We note strong agreement between the HS-DMC approach and that presented by Hirose and Marshall (2013) for daily and annual flows (Figure 5). Several pros and cons of each of these two methods are visible in Figure 5. 
Specifically, the HS-DMC method is inflated in 2010 due to a large precipitation event. Whereas the modeled data underestimates flow in 2009 and 2011 because data are only available from May1 to September 14, the time period in which glacier measurements and local climate data were obtained, and glacier melt had continued beyond this time interval in those years (Hirose and Marshall 2013).

Nonetheless, both methods are in high agreement with respect to the annual contributions of CSC to flow, though the HS-DMC method is slightly higher. In general, the HS-DMC method is expected to be greater than the distributed model because it includes changes to the perennial snowpack in the catchment as well as the glacier contribution.

Correlations between August flows obtained using the HS-DMC method and the approach of Stahl and Moore (2006) were generally weaker. However, both methods yielded similar trend magnitudes for the basins of this study. Though the Stahl and Moore (2006) method is easy in application and requires only quality climate and hydrometric data, the results do not provide volumetric changes as the trends are based on the residual error in the model. A significant advantage of the HS-DMC method is that has the capacity to determine volumetric or depth $(\mathrm{mm})$ values at multiple time-scales.

It is worth noting that the relationships between the HS-DMC method and the Stahl and Moore (2006) and Hirose and Marshall (2013) methods were based on the mean of all stream-pairs for the glacierized basin in question. Individual stream-pairs had varying correlation coefficients, with some much stronger than others. For example, the HS-DMC for all stream-pairs correlated to the Hirose and Marshall (2013) glacier melt in 2009 with an $r$ of 0.84, while individual stream-pair correlations ranged from 0.69 to 0.89 . This highlights one of the uncertainties in our method, in that stream-pairs would ideally be proximal, have similar catchment sizes, and elevations within a few $100 \mathrm{~m}$ of each other. These conditions were rarely available within our region and, to compensate for this fact, we use as many stream-pairs as available. In some cases, this led to higher correlations between the mean of all streampairs than any individual stream-pair. Both 2010 and 2011 correlations between the Hirose and Marshall (2013) glacier melt estimates and the mean HS-DMC were higher than any individual stream-pair that 
comprised the mean. This suggests, that because we use multiple streams, our estimates to some degree account for the regional climate variability expressed in non-glacierized streams, and therefore provide reasonable estimates of CSC contributions to flow.

The HS-DMC method is also in accord with the volumetric estimates of Scheifer et al. (2015), and, the ability of latitude, glacier cover, and elevation to capture up to $92 \%$ of the variability in our results implies that the data have captured a physical variation in time and space. Finally, fluctuations of Illecillewaet Glacier broadly mirror our estimated changes in CSC for the Illecillewaet drainage basin. The glacier retreated by more than $1 \mathrm{~km}$ between 1887 and 1962 (Champoux \& Ommanney 1986), advanced by 100 m until 1984 and then underwent continued retreat (Sidjak 1999, Bolch et al. 2010). Our record of CSC produced by the HS-DMC method does not indicate significant declines in until after1985 (Figure 8). These strong agreements between various measurements and modeling efforts and the HS-DMC method at different temporal and spatial scales lends credence to the HS-DMC method and provides a measure of confidence in the resulting trends.

In general, the slopes in the CSC time-series were steep and significant for the catchments with median glacier areas, between 1 and $8 \%$. The steeper slopes are likely due to the rapid retreat of glaciers and the snowline within these systems. Catchments with less than $1 \%$ glacier cover had the largest between-stream-pair errors and slopes were shallow (Table 1, Supplementary Figures). Larger between stream-pair error is potentially due to the fact that glaciers in these systems are small and perennial snow packs sparse. Because the CSC contributions to streamflow in these systems represents a smaller overall fraction of the annual streamflow, the contribution is harder to resolve using this method. The shallower slopes observed in glacierized basins below 50 degrees latitude probably also reflect the fact that these glaciers have already undergone substantial retreat, prior to the onset of monitoring. In the more northerly glacierized basins, steepness in slope varied but they were in general not significant. Between-stream-pair differences were smaller due to the larger annual contributions of CSC to streamflow. Canoe Creek, one of the most heavily glacierized basins, showed the highest percent contribution and a low slope. Canoe 
Creek is one of the most northern and the most heavily glacierized streams in the basin and does not appear to have yet entered a period of rapidly declining CSC contributions.

Our analyses revealed widespread declines in glacier and perennial snow contribution to flow, particularly in the median latitude reaches of the Columbia Basin (Figure 5). These results are similar to the conclusions of Stahl and Moore (2006) based on August streamflow that indicated most glaciers in the southern regions of British Columbia have passed the initial phase of increased meltwater production, and glacier snow and ice contributions are on the decline. Our analyses did not indicate significant declines for heavily glacierized catchments in the northern reaches of the Columbia Basin, suggesting that they have not yet passed peak glacial inputs to flow. These results are similar to those found by (Jost et al. 2012), that found no significant decreases in glacier contribution to flow in the Mica Basin in the northeastern reaches of the basin. It is, however, expected that as CSC contributions to rivers in the more northerly basins will begin to show significant declines once the initial phase of increased glacier discharge that accompanies the early stages of glacier recession has passed.

Because our data are based on watershed comparisons, declining trends in glacierized streams are potentially a result of declining specific discharges from higher elevation catchments due the declining area of permanent snow and ice, or a relative increase in specific discharge from lower elevation catchments. Because we do not see a relative decline in the annual higher elevation snowpack (or increase in the lower elevation annual snowpack), we interpret our trends as indicative of real changes in the net cryosphere storage. We did not account for the effects of logging or beetle kills, however, both these influences can increase specific discharges and peak flows in streams (Winkler et al. 2010). Although no significant change in the harvest rate has occurred in this region though the time period (personal communication, Peter Lewis, RPF, MFLNRO), it is likely that the Equivalent Clear-cut Area (ECA) has increased due to disturbance (beetle infestation, wildfire, and timber harvesting) and slow hydrologic recovery. These effects would make our estimates on streamflow declines more conservative as these 
forest impacts would lead to increases in streamflow. Such effects, however, are difficult to detect when the proportion of logged or disturbed area is relatively low (e.g., <25\%) (Buttle and Metcalfe 2011).

Our results indicate that declining cryosphere contributions to late summer streamflow should be considered presently in Columbia Basin management plans as there are several immediate and longerterm consequences of the loss of this resource. With respect to volumetric contributions, Brugman (1997) calculated that the loss of the Columbia Basin glaciers could lead to a reduction in the total August runoff in glacierized streams by 20 to $90 \%$. Our results indicated that glaciers currently contributed between 5 and $51 \%$ (Canoe Creek) of annual flow, though based on the snow water equivalent lapse rate the latter is potentially overestimated by $18 \%$ (Table 2), making the annual contribution of CSC to Canoe about $42 \%$. Regardless of the exact volumetric contribution, the method has proved to be cost effective, relatively easy, and reasonably accurate. Based on the strong agreements with other mechanistic models and measurements, this method is likely to accurately represent inter-annual changes in CSC to streamflow providing a quick reference as to whether or not CSC contributions to flow are increasing, decreasing, or remaining stable. This method can be applied to any glacierized region in the world with sufficient hydrometric data, and can help researchers and water managers target basins for more effective monitoring.

\section{Conclusion}

The HS-DMC method provides a simple procedure to estimate cryosphere storage contributions (CSC) to streamflow in regions where streamflow records exist. We interpret the time series produced by the method to reflect variations in the melt of glaciers and perennial snow that is cost-effective, relatively easy, and can be used on historical data. Though there are several confounding factors, including an inability to separate glacier melt from perennial snow melt, the method identifies volumetric changes that have occurred and can be anticipated as the equilibrium snow-line moves up in elevation. This method is easily applied to any glacierized watershed with sufficient hydrometric data from nearby non-glacierized 
streams. The results showed strong convergence with a variety of alternative methods used to assess similar questions surrounding the glacier contribution to flow in the Columbia Basin.

The method applied to glacierized streams in the south and central Columbia Basin of Canada revealed widespread and persistent declines in cryosphere storage contributions to streamflow. These observations should be considered in regional hydrologic models used to assess the timing and volume of future flow. Finally, the loss of ecosystem services and changes in biogeochemical cycling due to ongoing glacier recession and declining streamflow contributions should be assessed for the Columbia Basin region and other watersheds of the world.

\section{Acknowledgements}

This work was supported by the Ministry of Forests, Lands, and Natural Resource Operations, the Columbia River Integrated Environmental Monitoring Program, and the Columbia Basin Trust (Brahney and Menounos). Additional support is provided by the Natural Resources and Engineering Research Council of Canada and the Canada Research Chairs Program. We would like to thank Justin Robinson and the Selkirk Geospatial Research Center for technical support. 
1 Table 1 Changes in CSC to annual and August streamflow and the time period through which the results are evaluated. Declines are showed as

2 the slope $\left(\mathrm{mm}_{\mathrm{mear}}{ }^{-1}\right)$ and as the percent difference between the start year and the end year as determined by regression.

\begin{tabular}{|c|c|c|c|c|c|c|c|c|c|c|c|c|c|}
\hline \multirow[b]{2}{*}{ Stream } & \multirow[b]{2}{*}{ Latitude } & \multirow[b]{2}{*}{$\begin{array}{l}\text { Drainage } \\
\text { area } \\
\left(\mathrm{km}^{2}\right)\end{array}$} & \multirow[b]{2}{*}{$\begin{array}{l}\text { Glacier } \\
\text { Area } \\
\left(\mathrm{km}^{2}\right)\end{array}$} & \multirow[b]{2}{*}{$\begin{array}{c}\text { Percent } \\
\text { Cover }\end{array}$} & \multicolumn{3}{|c|}{ Annual } & \multicolumn{6}{|c|}{ August } \\
\hline & & & & & $\begin{array}{l}\text { Record } \\
\text { Years }\end{array}$ & $\begin{array}{l}\text { Average } \% \\
\text { contribution } \\
\text { to annual } \\
\text { flow }\end{array}$ & $\begin{array}{l}\text { fractional } \\
\text { inflation } \\
\text { based on } \\
\text { snow } \\
\text { lapse rate }\end{array}$ & $\mathrm{mm}$ year $^{-1}$ & $\begin{array}{c}\text { \% Change } \\
\text { from 1975- } \\
2012\end{array}$ & $\begin{array}{l}\text { Spearman } \\
\text { Rank } p\end{array}$ & $m m$ year ${ }^{-1}$ & $\begin{array}{l}\text { \% Change } \\
\text { from 1975- } \\
2012\end{array}$ & $\begin{array}{l}\text { Spearma } \\
\text { n Rank } p\end{array}$ \\
\hline Fraser & 52.98 & 1712.00 & 67.75 & $3.96 \%$ & $1956-2013$ & 38.27 & 0.23 & -1.28 & $-27 \%$ & $<0.01$ & -0.72 & $-39 \%$ & $<0.01$ \\
\hline Canoe & 52.73 & 306.00 & 58.41 & $19.09 \%$ & $1972-2012$ & 51.03 & 0.18 & -0.82 & $-5 \%$ & 0.85 & -0.56 & $-9 \%$ & 0.31 \\
\hline Blue & 52.12 & 273.00 & 7.84 & $2.87 \%$ & 1984-2012 & 9.01 & -0.09 & -2.30 & & 0.15 & -0.47 & & $<0.1$ \\
\hline Gold & 51.68 & 541.00 & 57.51 & $10.63 \%$ & $1973-2013$ & 48.50 & 0.25 & -2.33 & $-21 \%$ & 0.17 & -1.15 & $0 \%$ & 0.14 \\
\hline Goldstrea & 51.67 & 933.00 & 56.75 & $6.08 \%$ & $1964-2012$ & 14.19 & 0.12 & -1.79 & $-38 \%$ & $<0.05$ & -0.57 & $-47 \%$ & $<0.01$ \\
\hline Beaver & 51.51 & 1160.00 & 90.93 & $7.84 \%$ & $1985-2013$ & 23.13 & 0.16 & -1.50 & & 0.37 & -0.04 & & 0.81 \\
\hline Blaeberry & 51.48 & 588.00 & 43.85 & $7.46 \%$ & $1970-2011$ & 36.13 & 0.17 & -1.67 & $-25 \%$ & 0.24 & -0.75 & $-27 \%$ & $<0.1$ \\
\hline Kicking Hc & 51.30 & 1845.00 & 78.98 & $4.28 \%$ & $1974-2012$ & 36.50 & 0.24 & -0.58 & $-7 \%$ & 0.26 & -0.52 & $-24 \%$ & $<0.05$ \\
\hline Seymour & 51.26 & 805.00 & 16.84 & $2.09 \%$ & $1970-2013$ & 9.11 & 0.10 & -1.03 & $-27 \%$ & $<0.1$ & -0.34 & $-55 \%$ & $<0.05$ \\
\hline Illeciliewã & 51.01 & 1156.00 & 71.08 & $6.15 \%$ & $1964-2013$ & 13.88 & 0.15 & -2.38 & $-44 \%$ & $<0.01$ & -0.82 & $-52 \%$ & $<0.01$ \\
\hline Eagle & 50.94 & 972.00 & 22.43 & $2.31 \%$ & $1966-2011$ & 5.42 & 0.17 & -0.83 & $-34 \%$ & $<0.05$ & -0.18 & $-55 \%$ & $<0.01$ \\
\hline Spillimact & 50.90 & 1454.00 & 64.00 & $4.40 \%$ & $1964-2012$ & 29.49 & 0.20 & -0.95 & $-22 \%$ & 0.10 & -0.43 & $-32 \%$ & $<0.05$ \\
\hline Duncan & 50.64 & 1359.00 & 102.31 & $7.53 \%$ & $1964-2013$ & 14.80 & 0.18 & -1.87 & $-44 \%$ & $<0.05$ & -0.81 & $-53 \%$ & $<0.01$ \\
\hline Lardeau & 50.26 & 1633.00 & 16.55 & $1.01 \%$ & $1946-2013$ & 7.03 & 0.08 & -1.54 & $-55 \%$ & $<0.01$ & -0.40 & $-66 \%$ & $<0.01$ \\
\hline Fry & 50.08 & 585.00 & 7.84 & $1.34 \%$ & $1974-2013$ & 11.64 & 0.14 & -1.29 & $-36 \%$ & 0.10 & -0.50 & $-56 \%$ & $<0.05$ \\
\hline Kaslo & 49.91 & 444.00 & 2.50 & $0.56 \%$ & $1972-2012$ & 3.20 & 0.04 & 0.04 & $19 \%$ & 0.63 & -0.02 & $17 \%$ & 0.49 \\
\hline Keen & 49.87 & 87.00 & 2.71 & $3.11 \%$ & $1974-2012$ & 5.54 & -0.01 & -0.57 & $-20 \%$ & 0.42 & -0.15 & $-37 \%$ & $<0.1$ \\
\hline Elk & 49.87 & 1962.00 & 9.25 & $0.47 \%$ & $1972-2012$ & 10.40 & 0.11 & -0.08 & $-16 \%$ & 0.36 & -0.02 & $-20 \%$ & $<0.1$ \\
\hline Kootenay & 49.61 & 6254.00 & 33.12 & $0.53 \%$ & $1964-2013$ & 11.65 & 0.11 & -0.25 & $-16 \%$ & 0.26 & -0.05 & $-6 \%$ & $<0.1$ \\
\hline Bull & 49.49 & 1507.00 & 1.13 & $0.07 \%$ & $1946-2012$ & 7.80 & 0.34 & -0.56 & $-7 \%$ & $<0.01$ & -0.05 & $-12 \%$ & $<0.1$ \\
\hline
\end{tabular}




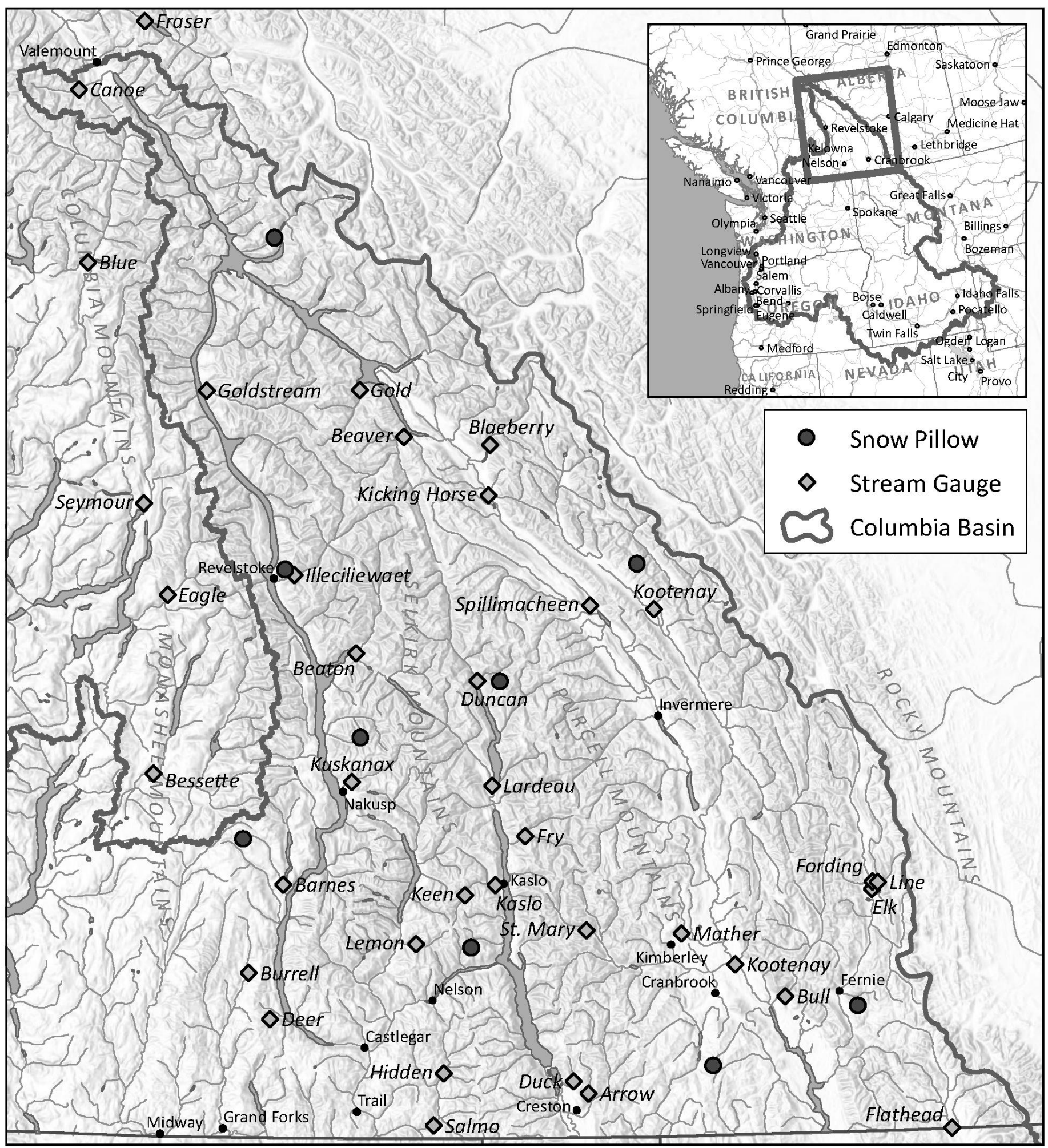

Sources: Esri, USGS, NGA, NASA, CGIAR, N Robinson, NCEAS, NLS, OS, NMA, Geodatastyrelsen,

5 Figure 1. The Columbia Basin of Canada. 

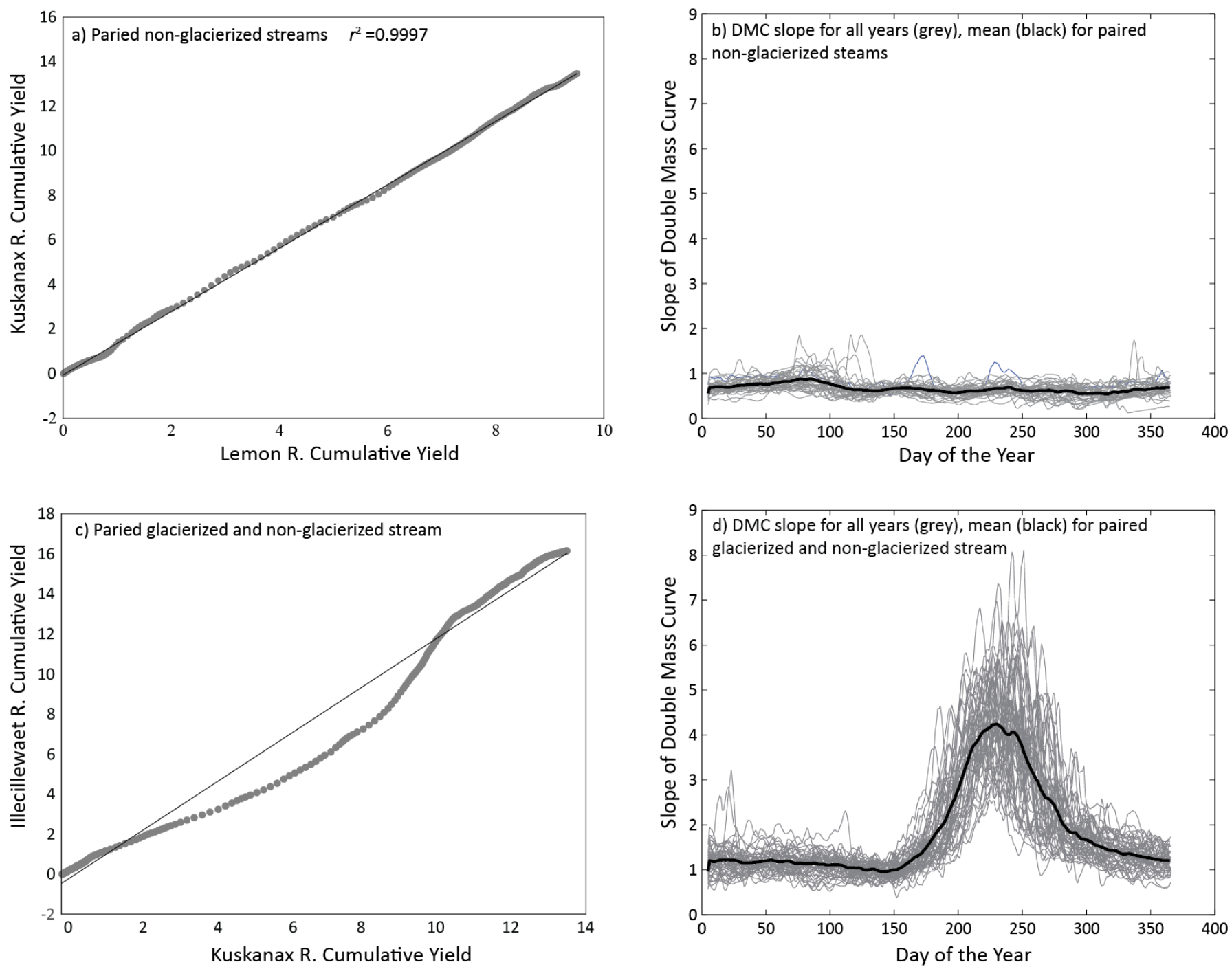

8 Figure 2. The DMC method for estimating the onset and termination of CSC to streamflow. Panel a and $b$

9 illustrate the example of two non-glaciated streams with no measurable difference in cumulative mass.

10 Panel $\mathrm{c}$ and d illustrate the example of a paired glacierized and non-glacierized stream. 


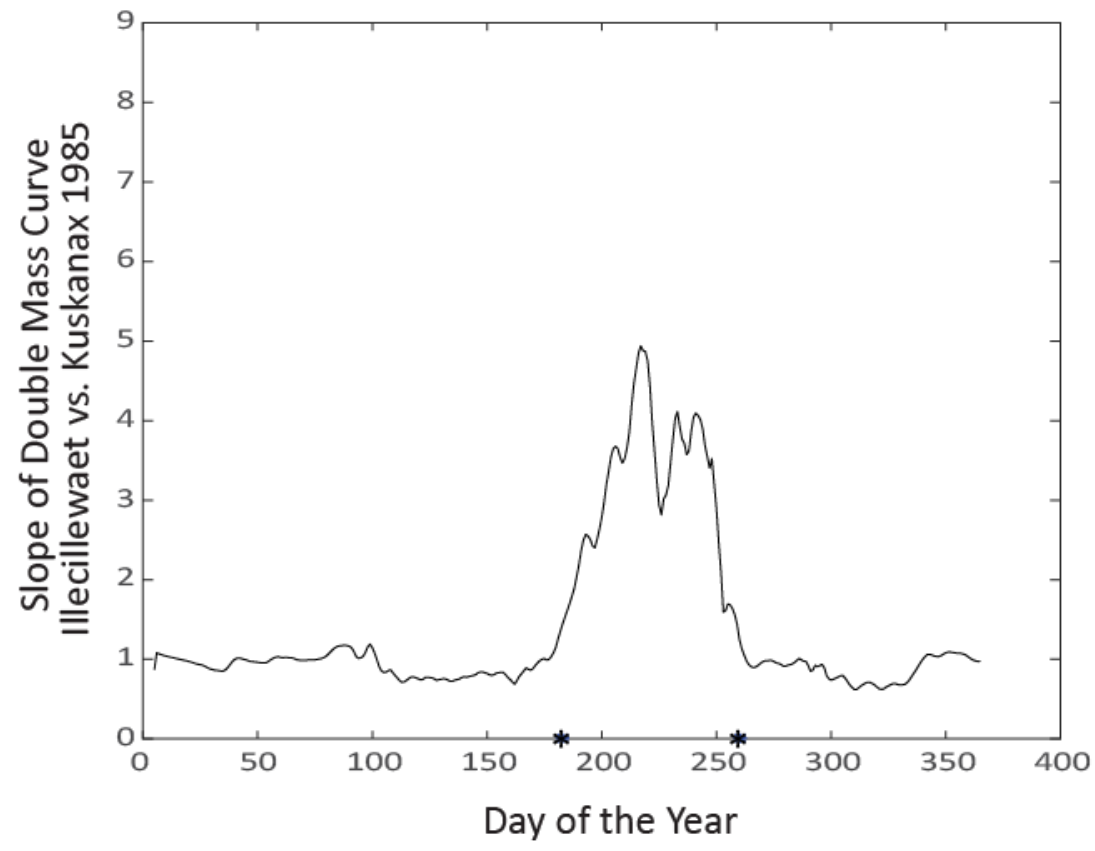

12

13 Figure 3. An example DMC for one year between the glacierized stream, Illecillewaet, and the non14 glacierized stream, Kuskanax.

15

16

17

18 

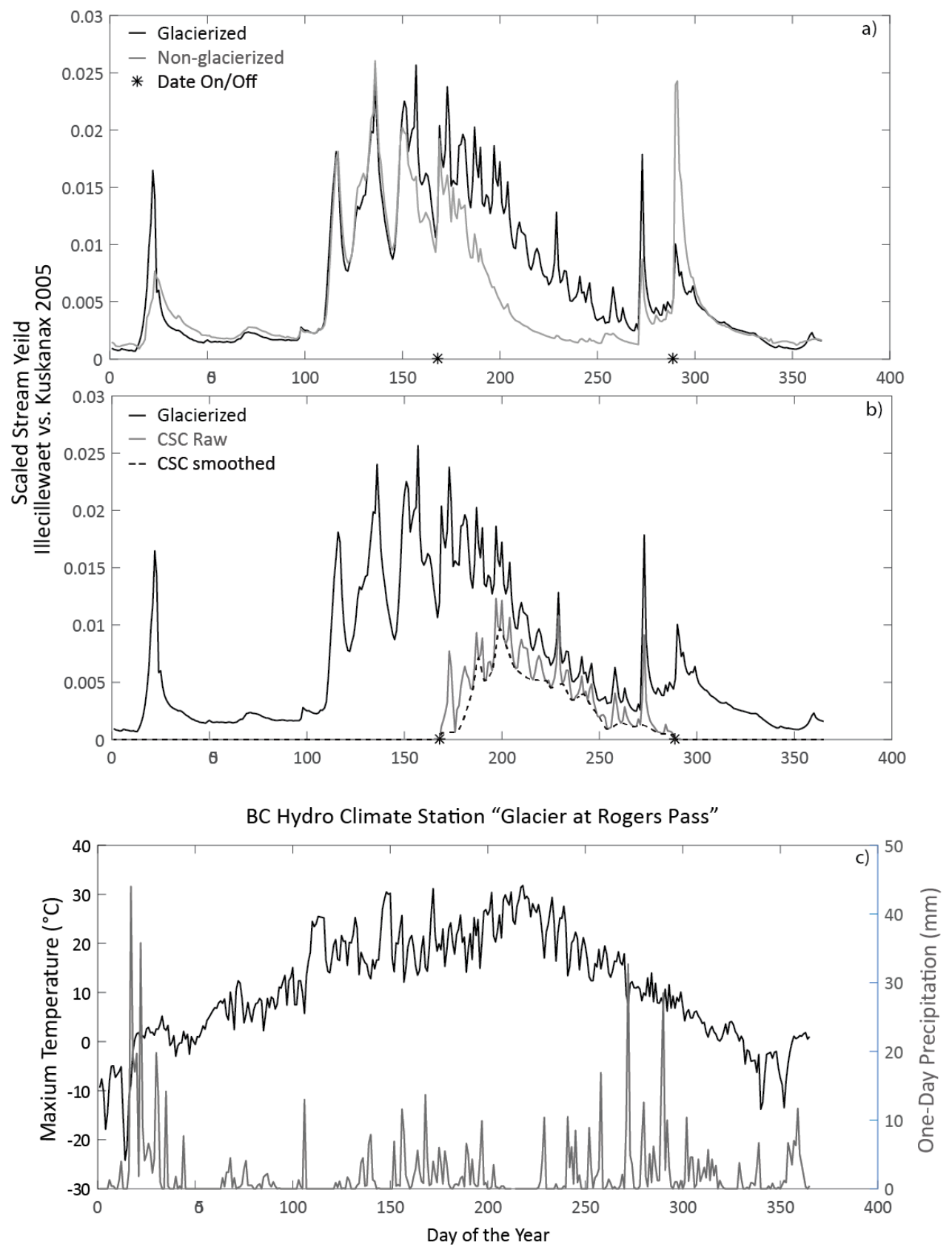

20 Figure 4. Example hydrographs illustrating the determination of CSC. Panel a shows a paired glacierized 21 and non-glaciered hydrograph. Panel b illustrates the raw and CRC smoothed estimate derived by

22 subtracting the non-glacierized hydrograph from the glacierized, the smoothed line illustrates the removal 23 of single precipitation events from the calculated sum. Panel c shows the climate variables from a nearby 24 climate station 


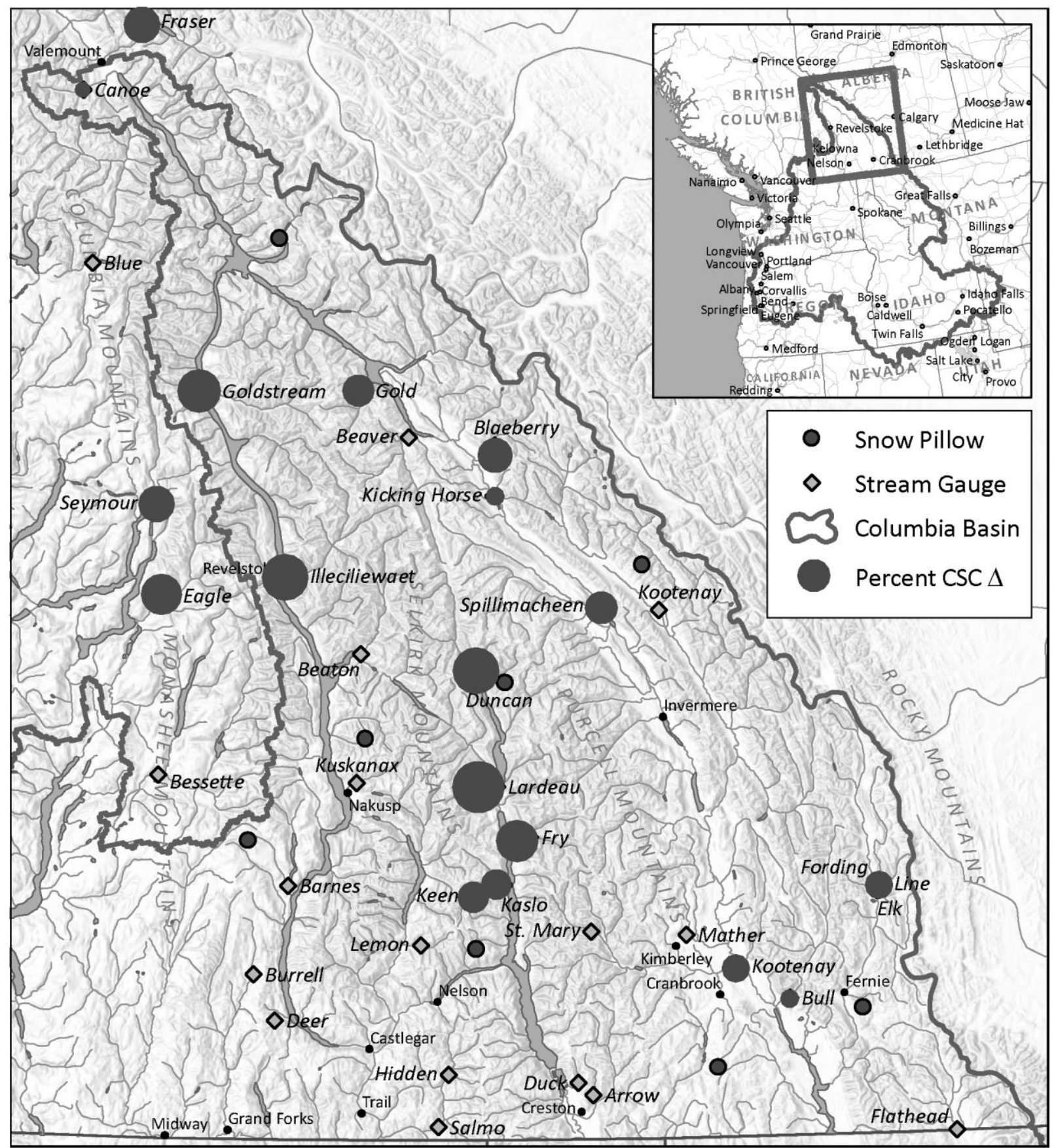

Sources: Esri, USGS, NGA, NASA, CGIAR, N Robinson, NCEAS, NLS, OS, NMA, Geodatastyrelsen, Rijkswaterstaat, GSA, Geoland, FEMA, Intermap and the GIS user community

27 Figure 5. Map of the Columbia Basin Region in BC showing percent declines for glacierized streams from 1975-2012. 

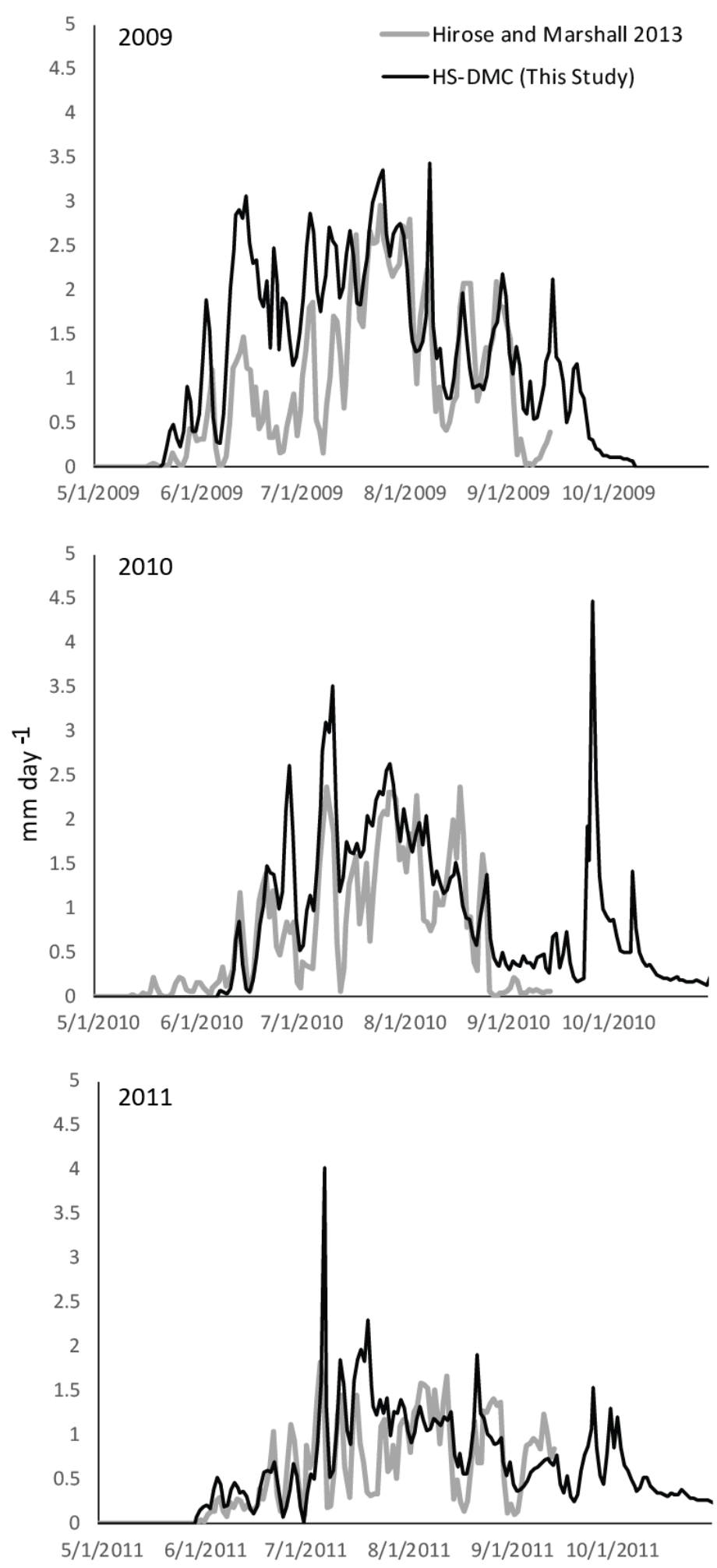

30 Figure 6. The mean of 5 stream-pairs for daily CSC to streamflow in mm day ${ }^{-1}$ by the HS-DMC method 31 in comparison to the distributed model of Hirose and Marshall (2013). 


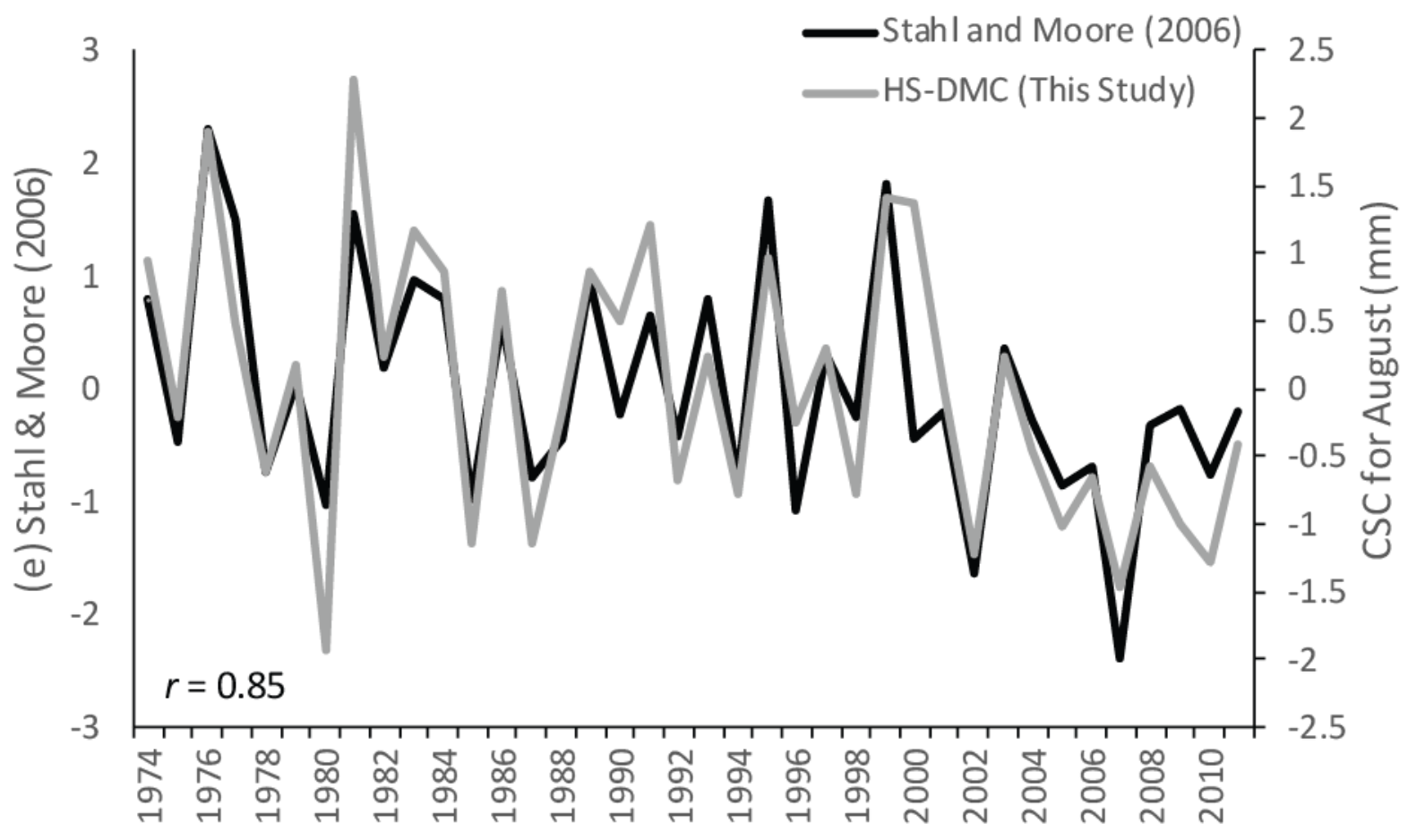

34 Figure 7. Example comparison between the Stahl and Moore (2006) method (see equation 4) for determining the glacier contribution to streamflow in August and the HS-DMC method for estimating CSC to streamflow for the month of August alone for the Kicking Horse River. 


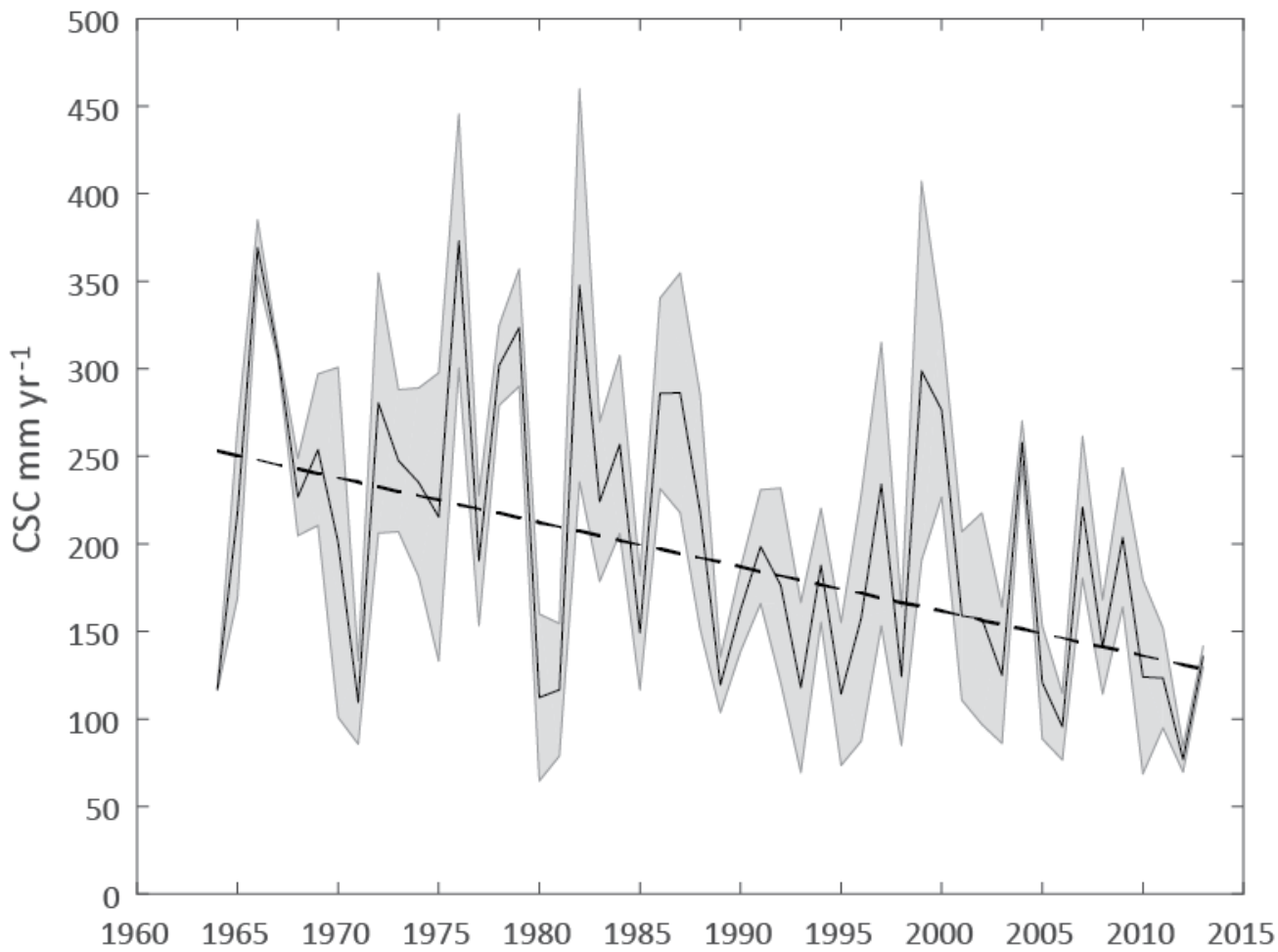

39 Figure 8. Mean (black) and 2 standard deviation (shade) estimate for annual CSC to streamflow of the $40 \quad$ Illecillewaet. 
42

43

44

45

46

47

48

49

50

51

52

53

54

55

56

57

58

59

60

61

62

63

64

65

66

67

68

69

70

71

72

73

74

75

76

77

78

79

80

81

82

83

84

85

86

87

88

89

90

Beedle, M. J., B. Menounos, B. H. Luckman, and R. Wheate. 2009. Annual push moraines as climate proxy. Geophysical Research Letters 36:n/a-n/a.

Beedle, M. J., B. Menounos, and R. Wheate. 2015. Glacier change in the Cariboo Mountains, British Columbia, Canada (1952-2005). The Cryosphere 9:65-80.

Bolch, T., B. Menounos, and R. Wheate. 2010. Landsat-based inventory of glaciers in western Canada, 1985-2005. Remote Sensing of Environment 114:127-137.

Brugman, M. M., S. A. Pietroniro, and J. Toyra. 1996. Development of Glacier Runoff Model Component: Analysis and Modelling of Glacier Runoff Contribution to the Columbia River Basin. Report, Summary Report Prepared for BC Hydro, first Draft, August 1996, NHRI, Environment Canada, Saskatoon. .

Buttle, J. M., and R. A. Metcalfe. 2011. Boreal forest disturbance and streamflow response, northeastern Ontario. Canadian Journal of Fisheries and Aquatic Sciences 57:5-18.

Canada, E. and C. C. (n.d.). Historical Climate Data. Government of Canada. Environment and Natural Resources. http://climate.weather.gc.ca/.

CBT. 2016. Columbia River Basin: Dams and Hydroelectricity. Web Page, Columbia Basin Trust. https://www.cbt.org/uploads/pdf/HydroPowerDams_Final_web.pdf.

Champoux \& Ommanney, C. S. L., A. 1986. Evolution of the Illecillewaet Glacier, Glacier National Park, BC, using historical data, aerial photography and satellite image analysis. Annals of glaciology 8:31-33.

Clarke, G. K. C., A. H. Jarosch, F. S. Anslow, V. Radic, and B. Menounos. 2015. Projected deglaciation of western Canada in the twenty-first century. Nature Geosci 8:372-377.

Cohen, S. J., K. A. Miller, A. F. Hamlet, and W. Avis. 2000. Climate Change and Resource Management in the Columbia River Basin. Water International 25:253-272.

Collins, D. N. 2008. Climatic warming, glacier recession and runoff from Alpine basins after the Little Ice Age maximum. Annals of glaciology 48:119-124.

Comeau, L. E. L., A. Pietroniro, and M. N. Demuth. 2009. Glacier contribution to the North and South Saskatchewan rivers. Hydrological Processes 23:2640-2653.

DeBeer, C. M., H. S. Wheater, S. K. Carey, and K. P. Chun. 2015. Recent climatic, cryospheric, and hydrological changes over the interior of western Canada: a synthesis and review. Hydrology \& Earth System Sciences Discussions 12.

Demuth, M. N. 2013. Glacier mass balance observations for Peyto Glacier, Alberta, Canada (updated to 2012). Spatially Referenced Data Set contribution to the National Glacier-Climate Observing System, State and Evolution of Canada's Glaciers. Web Page, Geological Survey of Canada . http://pathways.geosemantica.net/WSHome.aspx?ws=NGP_SECG\&locale=en-CA.

Dyurgerov, M. B., and M. F. Meier. 2005. Glaciers and the changing earth system: a 2004 snapshot. Book, Institute of Arctic and Alpine Research, University of Colorado, Boulder.

Fleming, S. W., and G. K. C. Clarke. 2003. Glacial Control of Water Resource and Related Environmental Responses to Climatic Warming: Empirical Analysis Using Historical Streamflow Data from Northwestern Canada. Canadian Water Resources Journal / Revue Canadienne des Resources Hydriques 28:69-86.

FLNRO. 2014. Automated and manual snow pillow data. Online Database, Ministry of Forests, Lands, and Natural Resource Operations. River Forecast Centre.

Gascoin, S., C. Kinnard, R. Ponce, S. Macdonell, S. Lhermitte, and A. Rabatel. 2011. Glacier contribution to streamflow in two headwaters of the Huasco River, Dry Andes of Chile. The Cryosphere:1099-1113.

Hari, R. E., D. M. Livingstone, R. Siber, P. Burkhardt-Holm, and H. GÜTtinger. 2006. Consequences of climatic change for water temperature and brown trout populations in Alpine rivers and streams. Global Change Biology 12:10-26.

Hirose, J. M. R., and S. J. Marshall. 2013. Glacier Meltwater Contributions and Glaciometeorological Regime of the Illecillewaet River Basin, British Columbia, Canada. Atmosphere-Ocean 51:416-435.

Hopkinson, C., and G. J. Young. 1998. The effect of glacier wastage on the flow of the Bow River at Banff, Alberta, 1951-1993. Hydrological Processes 12:1745-1762.

Huss, M. 2011. Present and future contribution of glacier storage change to runoff from macroscale drainage basins 
in Europe. Water Resources Research 47.

Jost, G., R. D. Moore, B. Menounos, and R. Wheate. 2012. Quantifying the contribution of glacier runoff to streamflow in the upper Columbia River Basin, Canada. Hydrol. Earth Syst. Sci. 16:849-860.

Liu, W., X. Wei, S. Liu, Y. Liu, H. Fan, M. Zhang, J. Yin, and M. Zhan. 2015. How do climate and forest changes affect long-term streamflow dynamics? A case study in the upper reach of Poyang River basin. Ecohydrology 8:46-57.

Luckman, B. H., K. A. Harding, and J. P. Hamilton. 1987. Recent glacier advances in the Premier Range, British Columbia. Canadian Journal of Earth Sciences 24:1149-1161.

Marzeion, B., J. G. Cogley, K. Richter, and D. Parkes. 2014. Attribution of global glacier mass loss to anthropogenic and natural causes. Science 345:919 LP-921.

Medwedeff, W. G., and G. H. Roe. 2016. Trends and variability in the global dataset of glacier mass balance. Climate Dynamics:1-13.

Moore, R. D., S. W. Fleming, B. Menounos, R. Wheate, A. Fountain, K. Stahl, K. Holm, and M. Jakob. 2009. Glacier change in western North America: influences on hydrology, geomorphic hazards and water quality. Hydrological Processes 23:42-61.

Muhlfeld, C., J. J. Giersch, F. R. Hauer, G. Pederson, G. Luikart, D. Peterson, C. Downs, and D. Fagre. 2011. Climate change links fate of glaciers and an endemic alpine invertebrate. Climatic Change 106:337-345.

Murdock J. Fraser, and C. Pearce (Eds), T. Q., and C. B. Trust. 2007. Preliminary Analysis of Climate Variability and Change in the Canadian Columbia River Basin: Focus on Water Resources 2006 . Page (P. C. I. Consortium, Ed.). Report, University of Victoria, Victoria BC.

NWPCC. 2016. Power Supply: Existing and New/Proposed Power Plants. Online Database.

Payne, J., A. Wood, A. Hamlet, R. Palmer, and D. Lettenmaier. 2004. Mitigating the Effects of Climate Change on the Water Resources of the Columbia River Basin. Climatic Change 62:233-256.

PCIC. (n.d.). BC Station Data. Pacific Climate Impacts Consortium Data Portal. https://www.pacificclimate.org/data/bc-station-data.

Schiefer, E., B. Menounos, and R. Wheate. 2007. Recent volume loss of British Columbian glaciers, Canada. Geophysical Research Letters 34:n/a-n/a.

Schnorbus, M. A., K. E. Bennett, A. T. Werner, and A. J. Berland. 2011. Hydrologic impacts of climate change in the Peace, Campbell and Columbia watersheds, British Columbia, Canada. Pacific Climate Impacts Consortium, University of Victoria, Victoria, BC 157.

Sidjak, R. W. 1999. Glacier mapping of the Illecillewaet icefield, British Columbia, Canada, using Landsat TM and digital elevation data. International Journal of Remote Sensing 20:273-284.

Stahl, K., and R. D. Moore. 2006. Influence of watershed glacier coverage on summer streamflow in British Columbia, Canada. Water Resources Research 42:W06201.

Stahl, K., R. D. Moore, J. M. Shea, D. Hutchinson, and A. J. Cannon. 2008. Coupled modelling of glacier and streamflow response to future climate scenarios. Water Resources Research 44:W02422.

WGMS. 2015. World Glacier Monitoring Service, latest glacier mass balance data. Summary of balance years 2013/2014 and 2014/2015. Web Page. http://wgms.ch/latest-glacier-mass-balance-data/.

Winkler, R. D., R. D. Moore, T. E. Redding, D. L. Spittlehouse, B. D. Smerdon, and D. E. Carlyle-Moses. 2010. Chapter 7. The Effects of Forest Disturbance on Hydrologic Processes and Watershed Response. in . Page (T. E. R. Edited by R.G. Pike R.D. Moore, and and K. D. B. R.D. Winkler, Eds.) Compendium of Forest Hydrology and Geomorphology in British Columbia. Book, B.C. Ministry of Forests, Mines and Lands. FORREX.

Yao, Y., T. Cai, X. Wei, M. Zhang, and C. Ju. 2012. Effect of forest recovery on summer streamflow in small forested watersheds, Northeastern China. Hydrological Processes 26:1208-1214.

Young, D. B., and C. A. Woody. 2007. Spawning Distribution of Sockeye Salmon in a Glacially Influenced Watershed: The Importance of Glacial Habitats. Transactions of the American Fisheries Society 136:452-459. 
142 Supplementary Table 1 Rivers in southeastern British Columbia used in this study. Glacier areas were

143 retrieved from the BC Freshwater Atlas, retrieved in 2014. Glacier extent years vary from 1997-2007.

\begin{tabular}{|c|c|c|c|c|}
\hline $\begin{array}{c}\text { Water } \\
\text { Survey of } \\
\text { Canada } \\
\text { Identifier }\end{array}$ & Stream & $\begin{array}{l}\text { Latitude } \\
\text { Decimal }\end{array}$ & $\begin{array}{l}\text { Longitude } \\
\text { Decimal }\end{array}$ & $\begin{array}{c}\text { Drainage } \\
\text { Area }\left(\mathrm{km}^{2}\right)\end{array}$ \\
\hline "08КА007 & Fraser & 52.982 & -119.004 & 1710 \\
\hline 08NC004 & Canoe & 52.731 & -119.384 & 306 \\
\hline 08LB038 & Blue & 52.116 & -119.301 & 272 \\
\hline 08NB014 & Gold & 51.677 & -117.717 & 540 \\
\hline 08ND012 & Goldstream & 51.668 & -118.597 & 934 \\
\hline 08NB019 & Beaver & 51.510 & -117.462 & 1157 \\
\hline 08NB012 & Blaeberry & 51.481 & -116.968 & 588 \\
\hline 08NA006 & Kicking Horse & 51.300 & -116.978 & 1846 \\
\hline 08LE027 & Seymour & 51.262 & -118.946 & 805 \\
\hline 08ND013 & Illeciliewaet & 51.014 & -118.083 & 1156 \\
\hline 08LE024 & Eagle & 50.936 & -118.799 & 955 \\
\hline 08NA011 & Spillimacheen & 50.904 & -116.406 & 1454 \\
\hline 08NH119 & Duncan & 50.638 & -117.047 & 1317 \\
\hline 08NH007 & Lardeau & 50.263 & -116.967 & 1635 \\
\hline 08NH130 & Fry & 50.081 & -116.784 & 584 \\
\hline 08NH005 & Kaslo & 49.908 & -116.952 & 443 \\
\hline 08NH132 & Keen & 49.871 & -117.120 & 94 \\
\hline 08NK016 & Elk & 49.866 & -114.868 & 1841 \\
\hline 08NG012 & St. Mary & 49.742 & -116.450 & 206 \\
\hline 08NG065 & Kootenay & 49.611 & -115.634 & 11500 \\
\hline 08NG002 & Bull & 49.493 & -115.364 & 1502 \\
\hline 08NK018 & Fording & 49.894 & -114.864 & 621 \\
\hline 08NE006 & Kuskanax & 50.277 & -117.748 & 330 \\
\hline 08NJ160 & Lemon & 49.697 & -117.389 & 181 \\
\hline 08NK022 & Line & 49.891 & -114.833 & 138 \\
\hline 08NF001 & Kootenay & 50.887 & -116.046 & 416 \\
\hline 08NE008 & Beaton & 50.736 & -117.729 & 97 \\
\hline 08NE077 & Barnes & 49.908 & -118.125 & 204 \\
\hline 08NN023 & Burrell & 49.589 & -118.311 & 221 \\
\hline 08NH084 & Arrow & 49.159 & -116.451 & 78 \\
\hline 08NH016 & Duck & 49.203 & -116.532 & 57 \\
\hline 08NP001 & Flathead & 49.001 & -114.476 & 1110 \\
\hline 08NE114 & Hidden & 49.234 & -117.238 & 57 \\
\hline 08NG076 & Mather & 49.725 & -115.925 & 135 \\
\hline 08NE074 & Salmo & 49.047 & -117.294 & 1166 \\
\hline 08NE088 & Deer & 49.425 & -118.190 & 82 \\
\hline 08LC039 & Bessette & 50.297 & -118.857 & 769 \\
\hline
\end{tabular}

145 